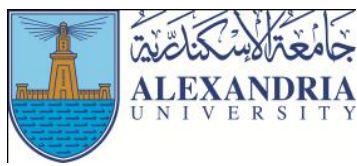

Journal of Applied Sports Science

June 2016, Volume 6, No. 2

www.jass.alexu.edu.eg

\title{
The Fact of Using Modern Social Media and Its Impact on the Investment of Leisure Time of University Youths
}

\author{
Rana Hosny Amin Othman ${ }^{1}$ \\ ${ }^{1}$ Teacher in the department of recreation, Faculty of Physical Education for Girls - Alexandria University, Egypt
}

\begin{abstract}
The progress of societies is known in individuals' conceive of the time value. What they are doing in order to control time reflects the cultural context of society. The time value can be organized and controlled to some extent. We can see it in how any society evaluate time through individuals' activities and their ability to take advantage of it in general and in leisure time in particular. Youth face a big problem of spending their leisure time. Leisure time has multiple negative dimensions, and affects economic aspects. Hence, developed countries are seeking to fill the leisure time of the youth by providing jobs in holidays, developing technical and technological programs, preparing various activities and announcing them in the media. Our society faces a great cultural openness where social media raises many divisive issues and concepts about modern social media and its effect on taking advantage of leisure time of the youth. Modern social media is characterized by many features such as integration, participation, openness and the absence of borders. The great growth of modern social media imposes many challenges in terms of its negative or positive effect on taking advantage of leisure time for its users.
\end{abstract}

\section{Study introduction and problem:}

$\mathrm{T}$ The progress of societies is known in individuals' conceive of the time value. What they are doing in order to control time reflects the cultural context of society. The time value can be organized and controlled to some extent. We can see it in how any society evaluate time through individuals' activities and their ability to take advantage of it in general and in leisure time in particular.

Youth face a big problem of spending their leisure time. Leisure time has multiple negative dimensions, and affects economic aspects. Hence, developed countries are seeking to fill the leisure time of the youth by providing jobs in holidays, developing technical and technological programs, preparing various activities and announcing them in the media.

Our society faces a great cultural openness where social media raises many divisive issues and concepts about modern social media and its effect on taking advantage of leisure time of the youth. Modern social media is characterized by many features such as integration, participation, openness and the absence of borders. The great growth of modern social media imposes many challenges in terms of its negative or positive effect on taking advantage of leisure time for its users.
Baker (2011) indicated that the mating between communication technology, information technology, computers and internet as a mean of modern social media, and the traditional means led to the emergence of modern means such as Online Newspaper, Instagram, Facebook, Twitter, YouTube, blogs, Digital Radio, etc. Each mean bears the burden of communicating with its audience. Therefore, the users shall choose the appropriate mean which suits their interests and inclinations.(3)

El Labban, Sherif Darwish (2000) explained the diversity of forms and objectives of modern social media that the youth use in general. Some of modern social media aims at communication generally and making friends, and others at formation of limited and specialized social networks. Finally, modern social media has many invisible roles that governments should care about in order to enhance its positive effect in taking advantage of leisure time of the youth, to develop the values of belonging to the country and to preserve the cultural and religious values (7: 102).

Samia and Neamat (2000) also indicated that educational institutions should concentrate on modern social media to guide the youth through lectures and seminars in order to clarify the optimal method for using the modern social media to ensure the integrity of information that university 
youths receive to express themselves and share their feelings and thoughts with others.(19)

The university aims at creating an aware generation contributes to the society's development and prosperity. Nowadays, the university is not only an educational institution, but it is an organization to which the student belongs during the most important stage of his life, to acquire science and knowledge, and satiate his desires and hobbies through participating in available activities at the university.

Leisure time, as illustrated by Muhsin Labib (1994), "is one of the most important problems facing the youth nowadays, so the various institutions of the country paid attention to such problem and to develop appropriate plans to solve it, so the youth does not deviate from the right way of the principles and ethics of the society." (15: 132).

Maher Abu El Maati (1999) added that "taking advantages of leisure time by recreational activities is deemed appropriate entrance to solve a lot of problems that may face the youth nowadays." (10: 158).

Mohammed Ali Mohamed also indicated that recreational activity is associated with leisure time and activity types the individual exercises in the non-business hours, which indicates that the individual chooses the activity as a result of an internal desire to exercise an activity(16:162).

The problem of leisure time is as important as other social problems facing the youth. It is related to the necessity of taking advantage of that time in many activities, and separating positive activities from negative ones. These activities are related to the family's contribution in taking advantage of leisure time of the youth, the most important activities they practice, the role of various social organizations within the society towards the youth, removing the main obstacles they face in taking advantage of their leisure time, and the relationship between taking advantage of leisure time of university youth and sexual distribution, specialization, school years, place of residence, family's income and parents' scientific qualifications.

Through analyzing previous studies dealt with leisure time and the youth (6) (9) (13) (14), the researcher found that the leisure time of the youth, as well as sophisticated tools produced by the scientific and cultural progress, lack of control of its mechanism and how to take advantage of it, its ability to attract the youth, especially the youth who did not enter the arena of life yet, require planning to take advantage of leisure time of the youth, to understand their needs and desires, to create awareness of the importance of taking advantage of their leisure time and to train them on taking advantage of it, by developing programs which achieve emotional, mental and healthy balance, so that leisure time could express their needs and desires, and thus give them positive types of behavior which reinforce positive qualities such as cooperation and friendship, a sense of loyalty and belonging, fair competition, initiative and granting, and social adjustment consistent with social norms. The study problem is centered in two significance things:

- Studying how the Alexandria University youths' use of modern social media effects their leisure time in an attempt to allow parents and workers in the field of the youth to recognize the vital cultural demands of the youth society and determine the nature of the negative effects that reduce their effectiveness and abilities by guiding the youth to take advantage of their leisure time to benefit from it, develop their affiliation to their society and preserve religious and cultural values prevailing in society.

- This study may meet scientific needs related to the nature of social and cultural life of the youth. And, It diagnoses the difficulties the youth face in taking advantage of their leisure time in an optimal manner, because the sociology of leisure time and recreation still in its early beginnings in the Arab Republic of Egypt with the use of modern social media.

\section{Study objectives:}

The study aims at identifying the fact of using modern social media and its effect on the investment of leisure time of university youths through:

- Identifying the times in which the youth use modern social media and the periods of use.

- Identifying the most modern social media programs used by university youths in their leisure time.

- Identifying the positive and negative effects of the youths' use of the modern social media programs on the investment of their leisure time.

\section{Study hypotheses:}

- When do the youth use modern social media and how long do they use it?

- What are the most modern social media programs used by university youths in their leisure time?

- What are the positive and negative effects of the youths' use of the modern social media programs on the investment of their leisure time? 


\section{Study Procedures:}

\section{Study Method:}

The researcher used survey descriptive method as it is appropriate to the nature of the study.

\section{Study community:}

Study community includes students (boys - girls) from Alexandria University youths of age (18 to 22 years) enrolled in the faculties of Alexandria University in the academic year (2014/2015). The researcher selected study community from the faculties of Alexandria University in
Alexandria and excluded the faculties of Alexandria University outside Alexandria to facilitate getting the sample and application of study tools.

\section{Study Sample:}

The sample was selected randomly from the students of Alexandria University enrolled in the faculties of Alexandria University in the academic year (2014/2015) of different academic levels, and excluded the faculties that have a preliminary year and separate the boys from girls. The following table illustrates the characterization of study sample:

Table (1)

numerical characterization of the sample according to the questionnaires distributed to the faculties

\begin{tabular}{|c|c|c|c|c|c|c|}
\hline Faculties & $\begin{array}{c}\text { Distributed } \\
\text { questionnaires }\end{array}$ & $\begin{array}{c}\text { Received } \\
\text { questionnaires }\end{array}$ & $\begin{array}{l}\text { Uncompleted } \\
\text { questionnaires } \\
\text { questionnaires }\end{array}$ & $\begin{array}{c}\text { Right } \\
\text { questionnaires }\end{array}$ & $\begin{array}{l}\text { Pilot } \\
\text { study }\end{array}$ & $\begin{array}{l}\text { Main } \\
\text { study }\end{array}$ \\
\hline Faculty of Education & 100 & 96 & 4 & 92 & 5 & 87 \\
\hline Faculty of Arts & 100 & 93 & 5 & 88 & 5 & 83 \\
\hline Faculty of Law & 100 & 94 & 3 & 91 & 4 & 87 \\
\hline Faculty of Commerce & 100 & 81 & 4 & 77 & 5 & 72 \\
\hline $\begin{array}{c}\text { Faculty of Tourism and } \\
\text { Hotels }\end{array}$ & 100 & 87 & 4 & 83 & 5 & 78 \\
\hline Faculty of Agriculture & 100 & 91 & 4 & 87 & 5 & 82 \\
\hline Total & 600 & 542 & 24 & 518 & 29 & 489 \\
\hline
\end{tabular}

Table (1) shows that the study sample included (29) male and female students as a sample for the pilot study, and (489) male and female students as a sample for the main study from the faculties of (Education - Arts - Law Commerce - Tourism and Hotels - Agriculture).

\section{Study tools:}

The following tools were used in data collection:

- Personal interview with university officials and experts to determine the validity and reliability of the study questionnaire.

- Questionnaire to collect data related to the study (prepared by the researcher) annex (1).

\section{Questionnaire design steps:}

The researcher took a look at previous studies and books and references (2) (5) (6) (7) (9) (11) to determine the axes and phrases of the questionnaire. Then, the questionnaire has been submitted to the experts in the field of Physical Education, specializing in management and recreation at faculties of Physical Education. Experts have agreed on the phrases of questionnaire and amended phrases, as described in annex (1).

Scientific transactions to the questionnaire:

Pilot study:

The researcher applied the questionnaire to a rationing sample, which includes (29) male and female students. It has been selected randomly from the study community in order to check validity and reliability of the questionnaire. Annex (2).

\section{Validity of content (validity of experts):}

Annex (2) explains the appropriateness of the questionnaire axes phrases, and the percentage of experts approvals ranged from $(77.78 \%$ to $100 \%)$. The researcher accepted the phrase which is approved by $75 \%$ or more, so she depended on all phrases due to the approval of experts on the phrases by more than $75 \%$.

\section{Validity of internal consistency of the phrases:}

Annex (3) shows that the internal consistency coefficient (correlation coefficient of phrase with the total of axis that belongs to it). Internal consistency coefficient values are high, ranged between $(0.558$ to 0.761$)$. These values are significant at the 0.01 , indicating the validity of phrases and that phrases are connected with the total axis, therefore measure what the axis measures. 
Annex (4), internal consistency coefficient of questionnaire axes, shows that internal consistency coefficient values are high, ranged between (0.585 to 0.754). These values are significant at the 0.01 , indicating the validity of phrases and that phrases are connected with the total axis, and therefore measure what the axis measures.

\section{Calculating the reliability of the questionnaire:}

Annex (5), Cronbach's alpha for the questionnaire axes, shows that Cronbach's alpha values are high, ranged between $(0.709$ to 0.733$)$. These values are significant at the 0.01 , which confirms that axes are in harmony with each other, characterized by reliability and they are integrated to contribute in the construction of the questionnaire. Any removal or addition of any of these axes my negatively affect the construction of the questionnaire. alpha coefficient value of the questionnaire was (0781), which is greater than alpha coefficient values of the axes, which confirms that the axes are in harmony with each other, characterized by reliability and they are integrated to contribute in the construction of the questionnaire. Any removal or addition of any of these axes my negatively affect the construction of the questionnaire.

Main study:

The researcher conducted the questionnaire from $15 / 3 / 2015$ To $30 / 4 / 2015$ on the sample. She aimed at applying the study tools to get the necessary data and to analyze it to get the conclusions.

\section{Statistical treatments:}

The researcher used the following statistical treatments:

Mean.

Chi-square.

Percentage.

\section{Discussion and conclusions:}

\section{Conclusions:}

First: sample responses to axe one phrases: variables of modern social media usage:

Annex (6) shows that the highest percentage of university youths' leisure time was daily $(87.12 \%)$, weekly $(12.07 \%)$ then monthly $(0.82 \%)$

Annex (7) shows that the highest percentage was for social media sites $(99.39 \%)$, followed by SMS $(98.36 \%)$, while, the lowest percentage was for electronic journalism $(26.99 \%)$.

Annex (8) shows that the youth used modern social media constantly $(87.53 \%)$, occasionally $(9.61 \%)$, and rarely $(2.86 \%)$.

Table (2)

times of modern social media usage during a normal day, $\mathrm{N}=489$

\begin{tabular}{|c|c|c|c|c|c|}
\hline \multirow{2}{*}{ variable } & \multirow{2}{*}{ Categories } & \multicolumn{3}{|c|}{ Statistical signifecense } \\
\cline { 2 - 6 } & & Frequency & Percentage\% & Chi-square & Order \\
\hline \multirow{4}{*}{\begin{tabular}{c} 
4. During your day, how long do you $\begin{array}{c}\text { une modern social media? } \\
\text { use }\end{array}$ \\
\cline { 2 - 6 }
\end{tabular}} & Lrom 30 minutes to less than an hour & 32 & 3.68 & $473.69 *$ & 5 \\
\cline { 2 - 6 } & From an hour to less than two hours & 159 & 32.52 & & 3 \\
\cline { 2 - 6 } & From two hours to less than three hours & 259 & 52.97 & 2 & 1 \\
\cline { 2 - 6 } & More than three hours & 21 & 4.29 & & 4 \\
\hline
\end{tabular}

* Significant at 0.05

Table (2) shows that the longest time to use modern social media during the day was less than 3 hours per day $(25.97 \%)$, followed by a less than two hours $(32.52 \%)$ and the lowest percentage was to be used less than 30 minutes $(3.68 \%)$. 
Table (3)

preference time to use modern social media $\mathrm{N}=489$

\begin{tabular}{|l|c|c|c|c|c|}
\hline \multirow{2}{*}{ Variable } & \multirow{2}{*}{ Categories } & \multicolumn{3}{|c|}{ Statistical signifecense } \\
\cline { 3 - 6 } & & Frequency & Percentage\% & Chi-square & Order \\
\hline \multirow{3}{*}{ 5. When do you prefer to use modern social media? } & From 6 am to 10 am & 13 & 2.66 & 319.7 & 5 \\
\cline { 2 - 6 } & From 10 am to 3 pm & 19 & 3.56 & 4 \\
\cline { 2 - 6 } & From 3 pm to 7 pm & 106 & 21.68 & 46.83 & \\
\cline { 2 - 6 } & From 7 pm to 12 am & 229 & 4 & 1 \\
\cline { 2 - 6 } & From 12 am to 6 am & 122 & 24.95 & & 2 \\
\hline
\end{tabular}

* Significant at 0.05

Table (3) shows that the time preferred by the youth to use followed by the period from 12 am to 6 am (24.95\%) and modern social media is from $7 \mathrm{pm}$ to $12 \mathrm{am}(46.83 \%)$, the lowest percentage is from 6 am to $10 \mathrm{am}(2.66 \%)$.

Table (4)

times of using modern social media $\quad \mathrm{N}=489$

\begin{tabular}{|c|c|c|c|c|c|}
\hline \multirow{2}{*}{ Variable } & \multirow{2}{*}{ Categories } & \multicolumn{3}{|c|}{ Statistical signifecense } \\
\cline { 3 - 6 } & & Frequency & Percentage \% & Chi-square & order \\
\hline \multirow{3}{*}{ 6. When do you use modern social media? } & Daily & 411 & 84.05 & $576.31 *$ & 1 \\
\cline { 2 - 6 } & Weekends & 68 & 13.91 & 2 \\
\cline { 2 - 6 } & Holidays & 10 & 2.04 & 3 \\
\hline
\end{tabular}

* Significant at 0.05

Table (4) shows that the youth are using modern social was in holidays $(2.04 \%)$. media daily $(84.05 \%)$, weekends $(13.91 \%)$, and less usage

Table (5)

contents you are keen to follow through modern social media (You can choose more than one answer) N= 489

\begin{tabular}{|c|c|c|c|c|c|}
\hline \multirow{2}{*}{ Variable } & \multirow{2}{*}{ Categories } & \multicolumn{4}{|c|}{ Statistical signifecense } \\
\hline & & Frequency & Percentage $\%$ & Chi-square & order \\
\hline \multirow{9}{*}{$\begin{array}{l}\text { 7. What are the main contents you are keen to } \\
\text { follow through social media? }\end{array}$} & Newsletters & 106 & 21.68 & $488.56 *$ & 8 \\
\hline & entertainment & 221 & 45.19 & & 2 \\
\hline & Religious topics & 193 & 39.47 & & 4 \\
\hline & Economy topics & 121 & 24.74 & & 6 \\
\hline & Culture and Literature & 188 & 38.45 & & 5 \\
\hline & Weather & 21 & 4.29 & & 9 \\
\hline & Goods and shopping & 231 & 47.24 & & 1 \\
\hline & Games and competitions & 196 & 40.08 & & 3 \\
\hline & Pictures of community stars & 107 & 21.88 & & 7 \\
\hline
\end{tabular}

* Significant at 0.05

Table (5) shows that the highest percentage was to the content of the goods and shopping (47.24\%), followed by the content of entertainment $(45.19 \%)$, then games and competitions $(40.08 \%)$, and the lowest rate was for weather $(4.29 \%)$
Second, sample responses to the second axis phrases: reasons for using modern social media: 
Table (6)

frequency, percentage and statistical signifecenses of university students' responses to the second axis: reasons for using modern social media $\quad \mathrm{N}=489$

\begin{tabular}{|c|c|c|c|c|c|c|c|c|c|c|c|}
\hline \multirow[b]{2}{*}{$\begin{array}{l}\text { Phrase } \\
\text { number }\end{array}$} & \multirow[b]{2}{*}{ Phrase } & \multicolumn{2}{|c|}{ Yes } & \multicolumn{2}{|c|}{ Occasionally } & \multicolumn{2}{|c|}{ No } & \multirow[b]{2}{*}{$\begin{array}{l}\text { Chi- } \\
\text { square }\end{array}$} & \multirow[b]{2}{*}{ Mean } & \multirow{2}{*}{$\begin{array}{c}\text { Total } \\
\text { agreemen } \\
\mathrm{t} \\
\text { percentag } \\
\mathrm{e}\end{array}$} & \multirow[b]{2}{*}{ Order } \\
\hline & & $\begin{array}{c}\text { Frequenc } \\
y\end{array}$ & $\begin{array}{c}\text { Percentage } \\
\%\end{array}$ & $\begin{array}{c}\text { Frequenc } \\
y\end{array}$ & $\begin{array}{c}\text { Percentage } \\
\%\end{array}$ & $\begin{array}{l}\text { Frequenc } \\
y\end{array}$ & $\begin{array}{l}\text { Percentage } \\
\%\end{array}$ & & & & \\
\hline 1 & Because it entertains me & 360 & 73.62 & 120 & 24.54 & 9 & 1.84 & $394.93^{*}$ & 1.72 & 85.89 & 5 \\
\hline 2 & $\begin{array}{l}\text { Discussing matters with } \\
\text { others }\end{array}$ & 334 & $68 . .30$ & 93 & 19.02 & 62 & 12.68 & $272.04 *$ & 1.56 & 77.81 & 12 \\
\hline 3 & $\begin{array}{c}\text { To feel comfortable and } \\
\text { relaxed }\end{array}$ & 285 & 58.28 & 197 & 40.29 & 7 & 1.43 & $247.71^{*}$ & 1.57 & 78.43 & 11 \\
\hline 4 & $\begin{array}{l}\text { Because my friends listen } \\
\text { to me }\end{array}$ & 273 & 55.83 & 132 & 26.99 & 84 & 17.18 & $118.42^{*}$ & 1.39 & 69.33 & 17 \\
\hline 5 & $\begin{array}{l}\text { To watch the latest TV } \\
\text { episodes and participate } \\
\text { in contests }\end{array}$ & 257 & 52.56 & 122 & 24.95 & 110 & 22.49 & $81.75^{*}$ & 1.30 & 65.03 & 21 \\
\hline 6 & $\begin{array}{l}\text { To visit blogs or social } \\
\text { media sites }\end{array}$ & 347 & 70.96 & 133 & 27.20 & 9 & 1.84 & $358.72^{*}$ & 1.69 & 84.56 & 6 \\
\hline 8 & $\begin{array}{c}\text { Because I like } \\
\text { participating in } \\
\text { competitions and games }\end{array}$ & 250 & 51.12 & 134 & 27.40 & 105 & 21.47 & 72.23 & 1.30 & 64.83 & 22 \\
\hline 9 & $\begin{array}{l}\text { Because I used to use } \\
\text { internet }\end{array}$ & 296 & 60.53 & 188 & 38.45 & 5 & 1.02 & $265.51^{*}$ & 1.60 & 79.75 & 9 \\
\hline 10 & $\begin{array}{l}\text { Playing games with } \\
\text { others }\end{array}$ & 243 & 49.69 & 189 & 38.65 & 57 & 11.66 & $112.34^{*}$ & 1.38 & 69.02 & 18 \\
\hline 11 & To learn new things & 345 & 70.55 & 123 & 25.15 & 21 & 4.29 & $336.74 *$ & 1.66 & 83.13 & 7 \\
\hline 12 & $\begin{array}{l}\text { To know how to act in } \\
\text { some situations that may } \\
\text { occur to me }\end{array}$ & 244 & 49.90 & 162 & 33.13 & 83 & 16.97 & $79.52^{*}$ & 1.33 & 66.46 & 20 \\
\hline 13 & $\begin{array}{l}\text { To dialogue with new } \\
\text { people to escape } \\
\text { boredom, monotony and } \\
\text { anxiety }\end{array}$ & 324 & 66.26 & 128 & 26.18 & 37 & 7.57 & $263.94 *$ & 1.59 & 79.35 & 10 \\
\hline 15 & When I become depressed & 247 & 50.51 & 123 & 25.15 & 119 & 24.34 & $64.98^{*}$ & 1.26 & 63.09 & 24 \\
\hline 16 & $\begin{array}{l}\text { When I don't find } \\
\text { someone to talk with }\end{array}$ & 246 & 50.31 & 220 & 44.99 & 23 & 4.70 & $182.44^{*}$ & 1.46 & 72.80 & 14 \\
\hline 17 & $\begin{array}{l}\text { To stay aware of what's } \\
\text { happening in the world }\end{array}$ & 422 & 84.30 & 67 & 13.70 & 0 & 0.00 & $631.08^{*}$ & 1.86 & 93.15 & 2 \\
\hline 18 & $\begin{array}{c}\text { To know the issues which } \\
\text { are not presented by } \\
\text { media }\end{array}$ & 243 & 49.69 & 165 & 33.74 & 81 & 16.56 & $80.54^{*}$ & 1.33 & 66.56 & 4 \\
\hline 19 & $\begin{array}{l}\text { To keep pace with the era } \\
\text { and feel that I am linked } \\
\text { with its updates }\end{array}$ & 366 & 74.85 & 111 & 22.70 & 12 & 2.45 & $409.29^{*}$ & 1.72 & 86.20 & 4 \\
\hline 20 & To be alone & 244 & 49.90 & 200 & 40.90 & 45 & 9.20 & $134.07 *$ & 1.41 & 70.35 & 16 \\
\hline 21 & $\begin{array}{c}\text { To be updated with new } \\
\text { developments }\end{array}$ & 240 & 49.08 & 232 & 47.44 & 17 & 3.48 & $196.36^{*}$ & 1.46 & 72.80 & 15 \\
\hline 22 & $\begin{array}{l}\text { It helps me organize my } \\
\text { time }\end{array}$ & 236 & 48.26 & 154 & 31.49 & 99 & 20.25 & $58.32^{*}$ & 1.28 & 64.01 & 23 \\
\hline 23 & $\begin{array}{l}\text { It helps me obtain } \\
\text { information about society } \\
\text { events and issues }\end{array}$ & 434 & 88.75 & 51 & 10.43 & 4 & 0.82 & $682.61 *$ & 1.88 & 93.97 & 1 \\
\hline 24 & $\begin{array}{l}\text { It distinguishes me from } \\
\text { the others }\end{array}$ & 336 & 68.71 & 132 & 26.99 & 21 & 4.29 & $313.21^{*}$ & 1.64 & 82.21 & 8 \\
\hline 25 & $\begin{array}{l}\text { It helps me forget life } \\
\text { worries and problems }\end{array}$ & 430 & 87.93 & 43 & 8.79 & 16 & 3.27 & $658.27 *$ & 1.85 & 92.33 & 3 \\
\hline
\end{tabular}

Chi-square is significant at $0.05=5.99$

Table (6) shows that the highest approval rate was for the youths' using of modern social media because it helps them get information about events and issues in the community $(93.97 \%)$, followed by to stay aware of what's happening in the world $(93.15 \%)$, and the less proportion was for to be used to vote on a life talk shows through a website $(25.20 \%)$.

Third: sample responses to the third axis phrases: the importance of using modern social media: 
Table (7)

frequency, percentage and statistical significances of university students' responses to the third axis phrases: the importance of using modern social media, $\mathrm{N}=489$

\begin{tabular}{|c|c|c|c|c|c|c|c|c|c|c|c|}
\hline \multirow{2}{*}{$\begin{array}{l}\text { Phrase } \\
\text { number }\end{array}$} & \multirow[b]{2}{*}{ Phrase } & \multicolumn{2}{|c|}{ Yes } & \multicolumn{2}{|c|}{ Occasionally } & \multicolumn{2}{|c|}{ No } & \multirow{2}{*}{$\begin{array}{l}\text { Chi- } \\
\text { square }\end{array}$} & \multirow[b]{2}{*}{ Mean } & \multirow{2}{*}{$\begin{array}{l}\text { Total } \\
\text { agreement } \\
\text { percentag } \\
\mathrm{e}\end{array}$} & \multirow[b]{2}{*}{ Order } \\
\hline & & $\begin{array}{l}\text { frequ } \\
\text { ency }\end{array}$ & $\begin{array}{l}\text { Percent } \\
\text { age } \%\end{array}$ & $\begin{array}{l}\text { Frequ } \\
\text { ency }\end{array}$ & $\begin{array}{l}\text { Percent } \\
\text { age } \%\end{array}$ & $\begin{array}{l}\text { frequ } \\
\text { ency }\end{array}$ & $\begin{array}{l}\text { Percent } \\
\text { age } \%\end{array}$ & & & & \\
\hline 1 & $\begin{array}{l}\text { It helps me raise my cultural } \\
\text { knowledge }\end{array}$ & 411 & 84.05 & 41 & 8.38 & 37 & 7.57 & *566.04 & 1.76 & 88.24 & 1 \\
\hline 2 & $\begin{array}{l}\text { It enables me to contact with } \\
\text { others without limitations }\end{array}$ & 254 & 51.94 & 222 & 45.40 & 13 & 2.66 & $* 210.20$ & 1.49 & 74.64 & 5 \\
\hline 3 & $\begin{array}{c}\text { It gives me the opportunity to } \\
\text { share and exchange opinions } \\
\text { with others who have the same } \\
\text { concerns }\end{array}$ & 266 & 54.40 & 211 & 43.15 & 12 & 2.45 & *219.10 & 1.52 & 75.97 & 4 \\
\hline 4 & $\begin{array}{l}\text { It helps me know the job } \\
\text { opportunities that suit my } \\
\text { specialization in different } \\
\text { incorporations }\end{array}$ & 323 & 66.05 & 101 & 20.65 & 65 & 13.29 & *239.56 & 1.53 & 76.38 & 3 \\
\hline 5 & $\begin{array}{l}\text { The relations are more friendly } \\
\text { than those in the reality }\end{array}$ & 244 & 49.90 & 212 & 43.35 & 33 & 6.75 & *158.66 & 1.43 & 71.57 & 9 \\
\hline 6 & $\begin{array}{c}\text { To send short messages to } \\
\text { others and receive their } \\
\text { opinions }\end{array}$ & 122 & 24.95 & 111 & 22.70 & 256 & 52.35 & *79.96 & 0.73 & 36.30 & 13 \\
\hline 7. & $\begin{array}{l}\text { It creates a friendly } \\
\text { environment with others. }\end{array}$ & 250 & 51.12 & 187 & 38.24 & 52 & 10.63 & $* 125.56$ & 1.40 & 70.25 & 10 \\
\hline 8 & $\begin{array}{l}\text { I feel confident in social } \\
\text { events thanks to my } \\
\text { experiences }\end{array}$ & 322 & 65.85 & 143 & 29.24 & 24 & 4.91 & *276.09 & 1.61 & 80.47 & 2 \\
\hline 9 & $\begin{array}{l}\text { I can not sit down a lot with } \\
\text { my family members }\end{array}$ & 252 & 51.53 & 211 & 43.15 & 26 & 5.32 & *177.88 & 1.46 & 73.11 & 7 \\
\hline 10 & $\begin{array}{l}\text { It develops my skills and helps } \\
\text { me communicate with, and } \\
\text { exchange experiences and } \\
\text { information with others who } \\
\text { have the same hobbies }\end{array}$ & 244 & 49.90 & 234 & 47.85 & 11 & 2.25 & *212.92 & 1.48 & 73.82 & 6 \\
\hline 11 & $\begin{array}{l}\text { It publishes the facts which } \\
\text { media tries to hide or which I } \\
\text { could not reach them }\end{array}$ & 234 & 47.85 & 233 & 47.65 & 22 & 4.50 & *182.96 & 1.43 & 71.68 & 8 \\
\hline 12 & $\begin{array}{c}\text { I can talk in sensitive things } \\
\text { which I can not reveal them to } \\
\text { others }\end{array}$ & 240 & 49.08 & 122 & 24.95 & 127 & 25.97 & $* 54.64$ & 1.23 & 61.55 & 11 \\
\hline 13 & $\begin{array}{l}\text { It allows compassion towards } \\
\text { certain groups in society }\end{array}$ & 132 & 26.99 & 172 & 35.17 & 185 & 37.83 & *9.36 & 0.89 & 44.58 & 12 \\
\hline
\end{tabular}

Chi-square is significant at level $0.05=5.99$

Table (7) shows that the highest approval rate about the importance of youths' using of modern social media was because it helps them raise their cultural information $(88.24 \%)$, followed by because it makes them feel confident $(80.47 \%)$, and the less proportion was because it allows them send SMSs (36.30\%).

Fourth: sample respones to the fourth axis phrases: the nature of using social media:

Table (8)

frequency, percentage and statistical signifecenses of university students' responses to the fourth axis phrases: the nature of using social media $\mathrm{N}=489$

\begin{tabular}{|c|c|c|c|c|c|c|c|c|c|c|c|}
\hline \multirow[b]{2}{*}{$\begin{array}{l}\text { Phrase } \\
\text { number }\end{array}$} & \multirow[b]{2}{*}{ Phrase } & \multicolumn{2}{|c|}{ Yes } & \multicolumn{2}{|c|}{ Occasionally } & \multicolumn{2}{|c|}{ No } & \multirow{2}{*}{$\begin{array}{c}\text { Chi } \\
\text { square }\end{array}$} & \multirow[b]{2}{*}{ Mean } & \multirow{2}{*}{$\begin{array}{c}\text { Total } \\
\text { agreement } \\
\text { percentage }\end{array}$} & \multirow[b]{2}{*}{ Order } \\
\hline & & $\begin{array}{l}\text { Frequ } \\
\text { ency }\end{array}$ & $\begin{array}{l}\text { Percent } \\
\text { age } \%\end{array}$ & $\begin{array}{l}\text { Frequ } \\
\text { ency }\end{array}$ & $\begin{array}{c}\text { Percent } \\
\text { age } \%\end{array}$ & $\begin{array}{l}\text { Frequ } \\
\text { ency }\end{array}$ & $\begin{array}{l}\text { Percent } \\
\text { age } \%\end{array}$ & & & & \\
\hline 1 & $\begin{array}{l}\text { I cancel my } \\
\text { plans to enjoy }\end{array}$ & 343 & 70.14 & 122 & 24.95 & 24 & 4.91 & *327.62 & 1.65 & 82.62 & 2 \\
\hline
\end{tabular}




\begin{tabular}{|c|c|c|c|c|c|c|c|c|c|c|c|}
\hline & it & & & & & & & & & & \\
\hline 2 & $\begin{array}{l}\text { I try to } \\
\text { download and } \\
\text { save what are } \\
\text { attractive in it }\end{array}$ & 285 & 58.28 & 198 & 40.49 & 6 & 1.23 & $* 250.05$ & 1.57 & 78.53 & 3 \\
\hline 3 & $\begin{array}{l}\text { I live with it } \\
\text { during using }\end{array}$ & 246 & 50.31 & 113 & 23.11 & 130 & 26.58 & *64.28 & 1.24 & 61.86 & 5 \\
\hline 4 & $\begin{array}{l}\text { I give it my } \\
\text { entire } \\
\text { concentration }\end{array}$ & 389 & 79.55 & 54 & 11.04 & 46 & 9.41 & $* 470.22$ & 1.70 & 85.07 & 1 \\
\hline 5 & $\begin{array}{l}\text { I perform } \\
\text { some other } \\
\text { tasks during } \\
\text { using it }\end{array}$ & 248 & 50.72 & 121 & 24.74 & 120 & 24.54 & *66.49 & 1.26 & 63.09 & 4 \\
\hline
\end{tabular}

Chi-square is significant at level $0.05=5.99$

Table (8) shows that $(85.07 \%)$ of youths give it their entire concentration, $(82.62 \%)$ cancel their plans to enjoy it, while $(61.86 \%)$ live with it while using.

\section{Second, discussion:}

Study conclusions show that all members of the study of different faculties have leisure time, varies depending on their study type. It reveals, also, that the youth use modern social media websites a lot in their leisure times. Therefore, it is clear that technology and information revolution have a great effect on university youths like the other world youths. This conclusion is consistent with Nabiha Alsamrai and Mohammed Al Qutos' study (2001). They found that most of youths' activities in their leisure time were negative, because of the lack of youths' vitality, which means they are passive recipients.

Study conclusions showed that the youth are using modern social media on a daily basis and for long periods. That was confirmed by the conclusions of Joshua Mark Bentley's study (2002) and (Moody Alayne et al.) study (2003).

Watching entertainment programs instead of cultural and scientific programs and other programs and activities means that the majority of youths who exercise these negative activities are unaware of the value of exercising these positive activities and its importance. If they exercise the positive activities, it will raise their scientific, cultural and psychological level, which is the most important factor in this important stage of their lives. Salim Ibrahim's study (2006) supported this conclusion. He found that long leisure time makes the sample members exercise many activities such as following Facebook and other modern social media sites.(18)(19)(22)

There are many obstacles face university youths when taking advantage of their leisure time. The most important and critical obstacle is the low awareness of the importance of taking advantage of leisure time. Parents are responsible for teaching their sons such matters, as their sons do not realize the value of time. This is a big problem on which institutions to which the youth belong educationally, socially and educationally concentrate, as it is one of the most important obstacles they face.(8)(11)

Osman Amin's study (2001) emphasizes that university activities have a significant role in guiding the youth to take advantage of their leisure time, as illustrated in this conclusion. After university activities, come family passivity, neglecting their demands or themselves in any way, not encouraging them to practice their favorite hobbies, and not supporting them morally or physically.

With the increasing effect of technology, most recent studies recommend that the youth should stay away, even temporarily, from modern technology, as they are in need for short break now and then to restore their spirit, enjoy normal life and return to reality away from cyberspace.

This is consistent with the opinion of Michelle Weil, coauthor of "TechnoStress: Coping with Technology@ work@ home@ play", that engaging in the technology world is like you are "lost" in space. One is lost in the internet world, games and conversation. She noted the time spent in front of computers, and the stress they are exposed to because of technology that is supposed to be developed to make life easier. And, that is consistent with the study conclusions.

The researcher concluded that modern technology entered strongly in the youth and adults lives. It has, remarkably, created for itself a large space in their lives because of its unlimited potentials of communication. In spite of the fact that communication is the basis of the social life of man, there are negative effects on the youth social life as a result of addiction to the use of these new technologies. Youth addiction to the use of modern technology, 
specifically communicative ones, indirectly affects the social life of these youths. Using internet has become an alternative for healthy social interaction with friends and relatives. They are spending long hours exploring multiple web sites, which means a change in the system of social values of individuals so as to promote excessive use of individual values, rather than social values, and reinforce the inclination of loneliness. Thus, this reduces the opportunities for interaction and social growth because these devices become "the only close friend". They accompanied them daily and fill their leisure time and loneliness. Since many of these modern means support the idea of building a virtual world (games, online chat), in which the youth turn, with frequent use, into slaves to a machine takes them away virtual distances while they are still motionless. It led them through the world of fantasy and virtual characters to wake up from slumber later and see that they are still sitting lonely in their places".

Conclusions, also, revealed that university youths are not only using modern social media for entertainment or relaxation, but also, as stated in the forefront of the conclusions, to obtain information, discuss it with others and learn new things. And, that is consistent with the results of Joshua Mark Bentley's study (2002).

It appears from conclusions that the youth use modern social media to get information about social events and issues more than using it to feel loneliness or entertainment and comfort, which is consistent with the results of (Alan B.Albarran et al., 2007) study.

\section{Recommendations:}

1- Raising awareness among the youth of taking advantage of their leisure time through educational institutions and media, and let them know the negative effect of using social media (telephone, internet).

2- Raising awareness among the youth of taking advantage of social media positively through lectures and publications as well as media.

3- Developing the sense of religion, homeland and affiliation in order to grant the recipient a strong immunity against all things would deprive him of his values and sources and things raking in his religious faith.

4- Observing the role of modern social media and its obviously negative effect on members of the society, especially the youth who are the backbone of society, and guiding the youth to take advantage of their leisure time through modern social media in order to publish his culture.
5- Activating family and university roles in controlling supervising the youth when using mobile phones and laptops through discussions with parents and the officials of university.

6- Conducting lectures and seminars about the programs through which the youth can activate social media role and its effect on their awareness to take advantage of their leisure time to benefit them and their society and protect society against religious, political and intellectual extremism.

7- Conducting scientific studies about the content presented in the social media programs and its effect on youths who are the most commonly used these programs in light of promotional activities for youths in their leisure time at the university.

\section{References:}

1- Atton, Chris.An Alternative Internet_ Radical Media_ Politics and Creativity (Edinburgh: EdinburghUniversity Press (2004).

2- Ayyad, Khayrat.'Internet Usage vs. Traditional Media Usage Among University Students In The UnitedArab Emirates', Journal of Arab \& Muslim Media Research, vol. 4, no. 1 (June 2011).

3- Baker, Andrea Jean. 'College Student Net-Radio Audiences: A Transnational Perspective', Radio Journal_International Studies in Broadcast \& Audio Media, vol. 8, no. 2 (January 2011).

4- Bentley, Joshua Mark. 'Contemporary Christian Radio Web Sites: A Uses And Gratifications Study’, M.S.Thesis, Oklahoma State University, Graduate College, 2010.

5- Cheatham, Kevin Andrew.'Blaze FM: An Examination of Student Listening Habits and the Uses and Gratifications Approach of Increasing Student Listenership', M.A. Thesis, Valdosta State University,College of Arts, 2012.

6- Effat Mokhtar Abdul Salam: (1993) vacuum "analytical study" to the interests and needs of university studentstime activities - scientific research published in the scientific journal of Physical Education and Sports Volume II, Faculty of Physical Education for Boys in Cairo - Helwan University

7- El Labban, Sherif Darwish: (2000) Contact the risks and challenges and social impacts of technology, the Egyptian Lebanese, Cairo, p. 102.

8- Jin, Y., Cropp, F. and Cameron, G. T. 'Chinese students and scholars in the U.S.: A study on their Chineseportal 
site use',Paper Submitted to the Mass Communication Division of the International Communication Association, Seoul, South Korea (http://www.empiricom.org/ glensite /PDF_articles/ChinesePortal.pdf), accessed 24 February 2012.

9- Kamal Imran: (1999) Youth and the benefits of investing spare time - a scientific research published in the journal Social Science - Volume 27 - Number 3 - Kuwait

10- Maher El-Maati and Others: (1999) the general practice of social work in the field of youth care - the market leading position at the University of Helwan

11- Malamud, Carl.A World's Fair for the Global Village (Cambridge, Massachusetts: MIT Press, 1997).

12- McQuail, Denis. McQuail's Mass Communication Theory, 5th edn. (London: Sage Publications, 2005).

13- Medhat Shawky Tous Mikhail: (1990) study of the size of free time at Assiut University students - PhD thesis unpublished - Faculty of Physical Education in Minya Minia University

14- Mohamed Kamal Sammanud, Medhat Tus: (1991), obstacles to the practice of sports activities and hobbies recreational favorite in the free time to the students of the Faculty of Physical Education in Assiut - Research published - Assiut Journal of Science and Arts of Physical Education - a scientific journal specialized - Faculty of Physical Education - Assiut University

15- Mohsen Abdel Razek Labib et al: (1994) Search the concerns of young people and the Egyptian youth and impediments to satisfy them - the central administration of the Research Youth and Sports - Cairo

16- Muhammad Ali Muhammad :vacuum in modern society time - Dar university knowledge - Alexandria
17- Said Aamr: (2006) ICT incentive or an obstacle to rehabilitation facilities S.m Arab International Forum on the rehabilitation of small and medium enterprises requirements in Arab countries, the University of Chlef 17.18 in April

18- Salim Ibrahim Ali Ibrahim: leisure and its relationship to juvenile delinquency: a field study of a sample of male delinquents and juvenile delinquents in Tripoli, unpublished Master Thesis, Academy of Graduate Studies,.

19- Samia Mohammed Jaber, Nemat Ahmed Osman (2000): Communication and Information (information technology), Dar knowledge University, Alexandria, p. 108

20- Sawhney, Harmeet and Seungwhan, Lee. 'Arenas of Innovation: Understanding New Configurational Potentialities of Communication Technologies',Media Culture \& Society, vol. 27, no. 3 (2005).

21- Nabiha Saleh al-Samarrai, and Mohamed Alqreis: (2001) "A field study at leisure at Nasser University students in the five" Arts and Humanities magazine, GS 1, Nasser University.,

22- Wimmer, Roget D. and Dominick, Joseph R. Mass Media Research_An Introduction, 5th edition (Belmont, CA: Wadsworth Publishing Company, 2000).

23- World Summit on the community AmuallomatGeneva in 2003 and Tunis 2005-http: //www.un.org/arabic/conferences/wsis/fact6.ht

24- Younis Arab world Alaketrona- site on the internetwww.arablaw.org 